\title{
Implementation Babinkamtibmas Completion Of Problems In Regency
}

\author{
Antonius Iwan Murdianto ${ }^{1}$
}

Abstract.Bhabinkamtibmas is a member of the Police whose existence is closest to the people in each village / urban, so that its role is essential in creating security and public order. This study aims to assess and analyze the role of Bhabinkamtibmas in helping to resolve problems that occur in the region, the obstacles and overcoming these obstacles. The method used in this research is the socio-juridical. Sources and types of data using primary data and secondary data. Methods of data collection is done through field studies and literature, while the method of data analysis using qualitative analysis. The results showed that Bhabinkamtibmas role in helping to resolve problems that occur in the region is as a facilitator and mediator. As a facilitator, bhabinkamtibmas provide premises, facilities and infrastructures for the mediation process is usually done in the village hall, and as a mediator Bhabinkamtibmas lead the mediation process. Obstacles encountered Bhabinkamtibmas in helping to resolve problems that occur in the region is the presence of a third party to interfere in the settlement and lack of public awareness both of which were in conflict as well as the surrounding community. Efforts to overcome these obstacles is to conduct an intensive approach to the victim, the offender and his family.

Keywords: Role; Bhabinkamtibmas; Problem Solving.

\section{Introduction}

Indonesian National Police is a state apparatus which has the main task of maintaining security and public order, conduct of law enforcement and provide protection, shelter, and service to the principle of legality society based (rechtmatigheid) which is set in 1945, Act No. 8 of 1981 of the Criminal Code, Act 2 of 2002 on the Indonesian National Police and other Law that specifically.,

Police function consists of two functions, namely the function of preventive and repressive functions. Preventive function is executed in order to provide protection, care, protection, and service to the community, and the repressive function as a law enforcement function. Police have peculiarities in the line of duty, namely to law enforcement and conduct of security, protection, and service to the community. Then the police attitude in society will always required to be protect, serve and protect.

Indonesian National Police aim to realize internal security, which includes maintenance of public order and security, order and the rule of law, the implementation of protection, shelter, and service to the community, as well how come public tranquility by respecting human rights (Article 4 of Act No. 2 of 2002). Along with the main task, the police are faced with the challenge of various crimes which disturb public order and security as cases of abuse, robbery, suicide bombings were carried out by terrorists, drug network, human trafficking and others.

In addition, there are also conflicts in various regions that give rise to SARA as the area

\footnotetext{
${ }^{1}$ Students of Masters (S2) of Law Faculty of Law Unissula Semarang email: iwanantonius80@gmail.com
} 
who want to be independent, anarchic demonstrations, inter-tribal fights, destruction of places of worship and others. All this evil arise due to not knowing the root of existing problems in social institutions in society. INP tend to see themselves solely as the authorities and the police force is seen by the public solely as a tool of the state, so that power approach even repressive measures often coloring the duties and authority of the police.

To be able to perform tasks in the prevention and control of internal security, the police have set up policies that are strategic, that such form of guidance to the security of spontaneous seeking his participation or community participation actively in the Development of internal security, the police as the spearhead of operational police and village / village as a base Bhabinkamtibmas activities; where this activity is known as community policing (Community Policing).

Coaching duties kamtibmas basically is obligatory for all members of the police, but structurally the task of guiding, coaching and counseling society is the task of the function Binmas, where the rate of KOD / Police executed by Satbinmas to spearhead the forefront implemented by Bhabinkamtibmas in rural or village which is base kamtibmas ${ }^{2}$,

In order to maintain security and public order sector in a country / region, the police demanded that easy to keep putting its personnel to be contacted by people in the area. Bhayangkara Public Order and Safety Trustees (Bhabinkamtibmas) is a member of the Police in charge of public order membinan security and kamtibmas and also the bearers of Community Policing (CBP) at the village / village ${ }^{3}$,

Bhabinkamtibmas is a member of the Police whose existence is closest to the people. Bhabinkamtibmas is a real police who serve the community. Bhabinkamtibmas a front guard or the cutting edge of police services (policing) at the level of village or village who daily mingle and interact with local communities. Bhabinkamtibmas first opportunity to provide police services in their respective working area.

Bhabinkamtibmas become very vital role in providing services or police assistance given the lack of a police station in village or in the villages. Bhabinkamtibmas a direct liaison between the community police institution in the community. Bhabinkamtibmas as officer (officer) leading from the police who daily meet with the community and address the problems that occurred.

Issues of security and public order disturbances including conflict does not arise for granted, but through several stages of the preliminary stage, the stage of the boiling point, the stage of violent conflict, and conflict mitigation phase. Bhabinkamtibmas who are capable and competent to eliminate the interference potential. The nearest police station is to village of rural police (police sector) and Polsubsektor (police sector). Although the communication tool has been able to reach remote areas, still a distance factor affects the speed of officers arrived on the scene. Not to mention the officers who will also serve requests from other regions. Urgency Bhabinkamtibmas presence in the villages as well as the presence of a nurse, paramedic, or midwife who

\footnotetext{
2 The law on village can bhabinkamtibmas escort (http://endriprastiono.blogspot.co.id Accessible 1Desember 2017)

${ }^{3}$ Police Chief Decree No. KEP / 6 / VI / 2014 dated July 292014 about Book Smart Bhabinkamtibmas p3.
} 
replaces the role of doctors in providing health services ${ }^{4}$,

The efforts of the police in bringing order and security by implementing the concept of patterned in today's society can be seen as the spearhead of the police, because it is directly the police officer dealing with community members or residents of local villages or with groups of local social and (public) for which he worked. The police officers who carry out their duties with a social approach must build rapport and genuine partnership and mutual benefit in creating a sense of security of citizens and the security atmosphere of the local environment.

One Bhabinkamtibmas role is as a mediator and facilitator in solving social problems that happend in rural communities / villages. Mediator implies any person or party that mediates disputes. While the facilitator is the person who gives or into a facility, the person who presents something.

Social problems is a phenomenon that exists in social life in a society that is perceived as a burden or harmful interference of community members. This harmful interference, including the violation of law, violation of religious norms, customary norms violations, and violations of social norm. As a forms of lawlessness that often occur are mild persecution.

Violations of the law can lead to conflict and annoyance to others and could lead to clashes between groups. Bhabinkamtibmas act as a mediator of disputes or as those who facilitate the settlement of disputes.

Problem solving method is applied by way Bhabinkamtibmas in solving social problems that occurred in the village or villages, an area auxiliaries. Bhabinkamtibmas positioning itself as a mediator or facilitator. This can be seen from the initial offer given to the parties that if you want to be processed according to the provisions of law or settled amicably in order to reach an agreement that is good and beneficial for all parties. Bhabinkamtibmas not impose their will and are ready to take the victim or the complainant to pour a police report at the police station ${ }^{5}$, In this case, Bhabinkamtibmas should act as a mediator and facilitator in the implementation of Community Policing.

Based on the description that has been described above, then formulated the issues to be discussed in this paper as follows: a. Bhabinkamtibmas obstacles faced in helping to resolve the problems in the community? b. How to efforts to overcome the obstacles faced by Bhabinkamtibmas in helping to solve the problems of criminal acts of persecution in the community?

\section{Research Methods}

Methods used are sociological juridical approach is a way of the procedures used to solve the problem by examining the secondary data research first and then proceed to conduct research on primary data in the field. ${ }^{6}$

\footnotetext{
4 Kusuma Dedi Siregar The Role of the Police Bhabinkamtibmas Applying Restorative Justice (http://www.tribratanewsjambi.com Accessed 30 November 2017).

${ }^{5}$ lbid.

${ }^{6}$ Ronny Hanitijo Soemitro 1989 Metode Penelitian Hukum dan Jurimetri Ghalia Jakarta p.9.
} 


\section{Results And Discussion}

\subsection{Constraints Faced In Helping Bhabinkamtibmas Problems Solving In Society.}

- The presence of a third party to interfere in the settlement of the problem. In handling the issue with the facilitator Bhabinkamtibmas aims to solve the problems through out of court. In other words, to promote peace between the perpetrator to the victim.

In practice, there are third parties who intervened in solving these problems. Such third parties could from relatives of victims who did not receive and complicate the peace efforts. For example, the victim's brother insisted on bringing the case to court, and influence the victim to resolve the issue through the courts. This raises doubts in the victim to make a peace agreement, despite the fact that the victim had intended to peace. This can complicate the process of resolving the problem. ${ }^{7}$

Aside from family parties, third parties who intervened in the settlement of criminal acts of persecution are NGOs / lawyers. In this case the lawyer / NGO can influence the thinking of the victim to continue the settlement of the case in court, with the lure will help carry out assistance during the judicial process runs. This will make Bhabinkamtibmas work, because the peace process could be hampered. ${ }^{8}$

- Lack of public awareness.

As is known, that the characteristics of the communities in the assortment. With such a pluralistic society there must be conscious of high legal and what is also a society with a low legal awareness. There are times when people are mediated not understand or do not understand the laws and rules that apply. Communities involved in the case, especially victims tend to be selfish act without thinking of the other party. This can complicate the process of mediation. ${ }^{9}$

\subsection{Measures To Overcome The Obstacles Faced By Bhabinkamtibmas In Helping To Resolve The Problems In Society.}

- Intensive approach

In case there are third parties who interfere in the settlement of the problem, then Bhabinkamtibmas seeks to intensive approach towards the victims and perpetrators. Here Bhabinkamtibmas should be able to control the situation in order not participate stuck in the problem. Bhabinkamtimas provide an understanding of the law against perpetrators and victims of the criminal acts of persecution. Bhabinkamtibmas provide a detailed explanation of the benefits in the event of peace between the two sides. Moreover, the causes of persecution are things that are trivial. Bhabinkamtibmas also explains how the legal process if it will proceed to court. Bhabinkamtibmas must be smart in giving approach so that the peace process is achieved without having to continue in court. ${ }^{10}$

\footnotetext{
${ }^{7}$ Interview with Iwan as Bhabinkamtibmas Polsekta Purwodadi on June 262018

${ }^{8}$ Interview with Sam Suyono as Chief of Unit Binmas Purwodadi police on June 272018

${ }^{9}$ Interview with Sam Suyono as Chief of Unit Binmas Purwodadi police on June 272018

${ }^{10}$ Interview with Sam Suyono as Police Chief of Unit Binmas in Purwodadi dated June 262018.
} 
For actors sometimes feel a dilemma when it found it difficult to pay for medical expenses or for the damage incurred due to the persecution he does. On the other hand, the victim wants the perpetrators punished according to his ways, but still hoping for compensation for any losses. If the case forward to trial the perpetrators are not necessarily willing to indemnify, otherwise if peace is feared offender will repeat his actions in the future.

Bhabinkamtibmas must try to react seriously to benefit all parties, since perpetrators and victims will also be fixed interact, because the victim and perpetrator resides in the same environment, together with the parents and families who are still on good terms with one another. Bhabinkamtibmaslah will be sensitive and understand the conditions that occur in the working area. Bhabinkamtibmas seeks to guide, encourage, direct, coordinate activities and mobilize including technical guidance for implementing something with a good, organized and thorough in order to achieve objectives and obtain maximum results. The goal is the creation of security and public order dynamic.

In addition to intensive approach with offenders and victims, Bhabinkamtibmas also coordinate with community leaders and village to help in problem solving. In this case the community leaders and village officials also give sense to the offender and the victim to undertake peace efforts.

- Conduct training and legal education of community

To address the lack of legal awareness, Bhabinkamtibmas conduct training and outreach to the community and community leaders. This effort is a preemptive effort, which aims to prevent the occurrence of crime.

Fostering community leaders aim to establish good relations with community leaders so willing to help the police in carrying out their duties are also in touch with the community itself. Mechanical or how its development through face to face, sambang / visits to provide information about the problems that are considered necessary, expressing congratulations on certain moments and offers help if known to require police assistance. Public figures are for instance the Chairman of the PKK; Chairman of the group of youth and adolescents; religious leaders and traditional leaders; and village from the RT / RW to the village chief. ${ }^{11}$

With good coordination between Bhabinkamtibmas and society, will create public confidence in the Bhabinkamtibmas, so that people will report to Bhabinkamtibmas when problems arise, so as to avoid vigilantism.

\section{Conclusion}

\subsection{Conclusions}

- Obstacles encountered Bhabinkamtibmas in helping to resolve the crime of persecution in Purworejo district police jurisdiction is the existence of a third party to intervene to solve the problem, namely from relatives / families of the victims or of NGOs / lawyers. There was also lack of public awareness both of which were in conflict as well as the surrounding community.

\footnotetext{
${ }^{11}$ Interview with Iwan as Bhabinkamtibmas Polsekta Purwodadi dated June 272018.
} 
- Measures to overcome the obstacles faced by Bhabinkamtibmas in helping to resolve the crime of persecution in Purworejo district police jurisdiction is to conduct an intensive approach to the victim, the offender and his family. In addition, guidance and legal counseling to people around the community leaders through face to face or sambang.

\section{Suggestions}

- Territorial integrity should be minimal at police station level to provide the Joint Agreement Letter form legalized by the police chief as a legal umbrella and given to all Bhabinkamtibmas in each region, so that there is uniformity in the manufacturing format of the Joint Decree on the conduct of the task Bhabinkamtibmas field.

- Socialization and counseling about laws against public awareness should be increased, given the many problems that occur in communities with the potential occurrence of a crime.

\section{Bibliography}

[1] Ronny Hanitijo Soemitro 1989 Metodologi Penelitian Hukum dan Jurimetri Ghalia Jakarta.

[2] The Code of Criminal Procedure

[3] Act No. 2 of 2002 on the Indonesian National Police.

[4] Police Regulation No. 3 of 2015 on Community Policing

[5] Police Chief Decree No. KEP / 6 / VII / 2014 dated July 292014 about Book Smart Bhabinkamtibmas.

[6] Law on the Village Can Babinkamtibmas escort? (http://endriprastiono.blogspot.co.id Accessed December 1 2017)

[7] Kusuma Dedi Siregar The Role of the Police Bhabinkamtibmas Applying Restorative Justice (http://www.tribratanewsjambi.com Accessed 30 November 2017). 